\title{
Pathogen-specific incidence rate of clinical mastitis in Flemish dairy herds, severity, and association with herd hygiene
}

\author{
Joren Verbeke, ${ }^{* 1}$ Sofie Piepers, ${ }^{*}$ Karlien Supré, $\dagger$ and Sarne De Vliegher* \\ *M-team and Mastitis and Milk Quality Research Unit, Department of Reproduction, Obstetrics, and Herd Health, Faculty of Veterinary Medicine, \\ Ghent University, 9820 Merelbeke, Belgium \\ †Milk Control Centre Flanders, 2500 Lier, Belgium
}

\section{ABSTRACT}

A one-year survey on clinical mastitis was conducted on 50 randomly selected commercial Flemish dairy herds to estimate the pathogen-specific incidence rate of clinical mastitis (IRCM). The severity of the cases and the potential associations with herd hygiene were studied. Participating producers sampled 845 cases and 692 dairy cows. The mean and median IRCM was estimated at 7.4 and 5.3 quarter cases per 10,000 cow-days at risk, respectively. A large between-herd variation was observed (range of 0-21.3). In general, the IRCM was lower in heifers compared with multiparous cows (2.9 vs. 11.0 quarter cases per 10,000 cow-days at risk). However, the overall IRCM in the first week after calving was higher in heifers compared with cows (43.4 vs. 31.6 quarter cases per 10,000 cow-days at risk). Streptococcus uberis (18.2\% of the cases) and Escherichia coli $(15.5 \%)$ were the most frequently isolated pathogens and no growth was observed in $19.9 \%$ of the cases. The majority of the cases $(63.1 \%$ ) were mild (only clots in milk). Moderate (hard quarter without general signs) and severe symptoms (systemic illness) were observed in 29.9 and $7.0 \%$ of the cases, respectively. Isolation of E. coli (vs. any other culture result) was more likely in moderate and severe cases compared with mild cases. Overall IRCM and E. coli IRCM were higher in dirty compared with clean herds based on udder hygiene scores (9.0 and 1.7 vs. 6.0 and 0.6 quarter cases per 10,000 cow-days at risk, respectively). This study broadens the knowledge on clinical mastitis in Flemish dairy herds and underlines the high risk of CM in earlylactation heifers, the role of the so-called environmental pathogens, and herd hygiene.

Key words: clinical mastitis, incidence rate, severity, herd hygiene

Received March 27, 2014.

Accepted August 10, 2014.

${ }^{1}$ Corresponding author: Joren.Verbeke@UGent.be

\section{INTRODUCTION}

Mastitis is one of the most common diseases in dairy cattle. The inflammatory reaction primarily occurs in response to bacterial IMI and impairs milk quality (Ma et al., 2000; Santos et al., 2003). The disease is accompanied by clinical signs [clinical mastitis (CM)] or presents itself without observable signs (subclinical mastitis).

Several countries have reported incidence rate of CM (IRCM) data, ranging from 5.5 quarter cases per 10,000 cow-days at risk in French herds with a low bulk milk SCC (BMSCC) to 12.9 quarter cases per 10,000 cow-days at risk in randomly selected herds in England and Wales (Barkema et al., 1998; Barnouin et al., 2005; Bradley et al., 2007; Olde Riekerink et al., 2008; Wolff et al., 2012). In contrast to subclinical mastitis (Piepers et al., 2007), there is a general lack of information on the occurrence of CM in Flanders. As for most Flemish dairy herds cases are not recorded and rarely sampled for culture, the exact incidence of CM remains unknown. Yet, according to an internet questionnaire performed by P. Passchyn, S. Piepers, and S. De Vliegher (Ghent University, Ghent, Belgium, unpublished data), 300 dairy producers estimated that $46 \%$ of the Flemish dairy cows suffer at least once per year from CM. Because the majority of questioned producers admitted not to keep disease records, the latter estimate might differ substantially from the actual IRCM in Flanders.

In studies performed in the Netherlands, Canada, and Ireland, Staphylococcus aureus was the most frequently isolated pathogen isolated from CM cases (Barkema et al., 1998; Olde Riekerink et al., 2008; Keane et al., 2013), whereas Streptococcus uberis and Escherichia coli were the most frequently isolated pathogens in studies performed in the United Kingdom (Bradley et al., 2007) and the United States (Oliveira et al., 2013). Because management systems differ between regions (e.g., Olde Riekerink et al., 2008) and dairy farming and mastitis control evolve over time (Bradley, 2002), regular CM studies at regional or national level remain indispensable for adapted mastitis prevention programs and development of novel prevention and control tools. 
In 2012, Strep. uberis and E. coli were the most frequently isolated pathogens from samples of CM cases submitted to the Milk Control Centre (MCC) Flanders (MCC Vlaanderen, Lier, Belgium), the largest milk laboratory in Flanders (Milk Control Centre Flanders, 2012). Although the included herds and cases are not randomly selected, the results suggest these so-called environmental pathogens to be the main cause of CM in Flanders. Reducing exposure of teats with manure and organic materials is pivotal in the prevention of environmental mastitis (Smith and Hogan, 1993). Schreiner and Ruegg (2003) developed a 4-point scale to score udder hygiene and reported that cows with a higher udder hygiene score (UHS; dirtier) had higher SCC values and were more likely to have subclinical mastitis. Using the same scoring system, Breen et al. (2009) identified high UHS as a cow-level risk factor for $\mathrm{CM}$ in general and for E. coli CM specifically. It remains unclear whether hygiene issues can be detected as risk factors for CM in Flanders, Belgium, as well.

Signs of CM range from abnormal milk to systemic illness, with the severity of cases depending on both cow and pathogen factors (Burvenich et al., 2003; Bannerman et al., 2004; Schukken et al., 2011). Oliveira et al. (2013) recently characterized CM on large dairy herds in Wisconsin and reported that systemic signs of illness were more likely to be observed in gram-negative cases. Escherichia coli was isolated in 12.5, 22.3, and $48.3 \%$ of the mild, moderate, and severe cases, respectively. To the best of our knowledge, no scientific information on signs of CM is available in Flanders, let alone a link with the associated pathogens. Yet, as in other regions, E. coli mastitis is often used as a synonym for severe CM.

The primary objective of this study was to estimate the pathogen-specific IRCM in Flanders, Belgium. Additionally, associations between the culture result and the reported severity and between (pathogen-specific) IRCM and herd hygiene were studied.

\section{MATERIALS AND METHODS}

\section{Herds and Study Design}

Clinical mastitis was monitored at the cow level (experimental unit) on randomly selected dairy herds (sampling unit) during $1 \mathrm{yr}$. The sample size for this study was estimated at 42 herds, using the following formula (Dohoo et al., 2003): $n=\frac{Z_{\alpha / 2}^{2} p q}{L^{2}}=\frac{1.96^{2} \times 0.46 \times 0.54}{0.15^{2}}$, where $n=$ number of herds needed to estimate the incidence rate, $Z_{\alpha / 2}=$ 95th percentile of a standard normal distribution, $p=$ a priori estimate of the proportion set at 0.46 (P. Pass- chyn, S. Piepers, and S. De Vliegher, Ghent University, Ghent, Belgium, unpublished data), $q=1-p$, and $L$ $=$ margin of error set at 0.15 .

To allow for noncompliance, 67 herds were randomly selected from the database of the MCC Flanders comprising all Flemish dairy producers $(\mathrm{n}=5,261)$ using the Excel RAND function (Excel 2010; Microsoft Corp., Redmond, WA). Thirteen, 4, 7, 19, and 24 herds were contacted in the provinces Antwerp, Flemish Brabant, Limburg, East Flanders, and West Flanders, respectively, matching the distribution of dairy herds over the 5 Flemish provinces $(19,6,10,28$, and $37 \%$, respectively; Federal Public Service Economy, Small and Medium Enterprises, Self-Employed, and Energy, 2011). No inclusion criteria were applied. Fifty-three producers agreed to participate in this study (response rate of $79 \%$ ). The main argument for noncompliance was lack of time $(\mathrm{n}=7)$, followed by planned retirement $(\mathrm{n}=3)$. The 4 remaining producers gave no specific argument for not participating.

The selected dairy herds were visited at the beginning of the study between September and October 2012. At that time, the study details were discussed with the producers and herd veterinarians, a questionnaire was filled out, and observations were made (see further). From then on, producers were asked to take a single sample from each quarter showing signs of CM during the 12-mo study period. Signs of CM were defined as visible abnormalities in the udder or milk, indicating udder inflammation, and were detected by examination of foremilk and the udder before milking. In herds with an automated milking system (AMS), producers examined foremilk and the udder of cows with changes in sensor data (electrical conductivity, color, and yield), reduced milking frequency, or visual abnormalities (e.g., swelling or redness of the udder). Thresholds were set by the producer. Dry cows were monitored by visual observation. Sample materials were provided and sampling procedures were explained as well as the importance of an aseptic sampling procedure. Sampling date, cow identification, quarter position, and clinical signs (absence or presence of clots in milk, a hard quarter, or systemic illness) were recorded by the producer as well. Cases were categorized as mild (only clots in milk), moderate (hard quarter but no general signs), or severe (signs of systemic illness) similar to the categorizations of Pinzón-Sánchez and Ruegg (2011). Samples were frozen on farm for one to several weeks and collected by the herd veterinarian. A courier of the Flemish Animal Health Service (DGZ) transported the samples from the veterinary practice to the MCC Flanders where bacteriological culture was performed. Three herds were omitted from the analysis during the study period because producers admitted 
halfway through the study that they were not sampling all the cases, resulting in 50 herds and 4,133 cows to be included in the final data set.

Producers were motivated to sample each single case by making the culture results available to them as soon as possible, by paying an incentive of $€ 3$ per collected sample, by performing a secondary herd visit between February and March 2013 to discuss the preliminary results, and by contacting them at least once every 2 mo by phone. We kept herd veterinarians actively involved in the project by sharing all culture results from all herds they were associated with, inviting them to join both herd visits, and financially supporting them to keep track of the herd administration. Both producers and herd veterinarians were invited to a meeting in October 2013, after completion of the survey, to discuss the results and receive a summary with herd-specific results, as was promised at the onset of the study. Both producers and veterinarians were aware of this initiative at the start of the study.

\section{Herd Hygiene}

Udder hygiene was scored for 20 randomly selected lactating cows during both herd visits performed by the first author as described by Schreiner and Ruegg (2003). In herds with less than 20 lactating cows, all lactating cows were scored. The proportion of cows having UHS 3 or 4 was calculated for each visit. Herds having an average proportion $>50 \%$ over the 2 visits were categorized as dirty; other herds were categorized as clean.

\section{Cow Data}

Cow-level records [calving date(s), parity, and culling date] were retrieved from DHI records for herds participating in the DHI program and from the identification and registration system of the Animal Health Service Flanders (Drongen, Belgium) for other herds.

\section{Bacteriological Culture}

Bacteriological culture was based on National Mastitis Council guidelines (NMC, 1999) and performed at the MCC Flanders. From each thawed sample, $10 \mu \mathrm{L}$ of milk was spread on blood-esculin and MacConkey agar and incubated aerobically for 24 to $48 \mathrm{~h}$ at $37^{\circ} \mathrm{C}$. Samples were considered to be culture positive if one or more colonies were observed $(\geq 100 \mathrm{cfu} / \mathrm{mL})$. Identification of bacteria was done by Gram staining, inspection of the colony morphology, and biochemical testing. Catalase tests were performed to differentiate gram-positive cocci as catalase-positive or catalase-negative cocci.
Staphylococci were identified as Staph. aureus or nonaureus staphylococci, referred to as Staphylococcus spp. throughout this paper, by colony morphology, hemolysis patterns, and DNase tests. Isolates of the StreptococcusEnterococcus group were differentiated as esculin-positive or esculin-negative cocci. Streptococcus uberis was distinguished from other esculin-positive cocci by incubation in $\mathrm{NaCl} 6.5 \%$ medium and bile esculin agar. Christie, Atkins, and Munch-Petersen (CAMP) tests were used to differentiate esculin-negative cocci as Streptococcus agalactiae or Streptococcus dysgalactiae. Gram-negative bacteria were identified by colony morphology, lactose fermentation on MacConkey agar, incubation in sulfideindole-motility (SIM) medium, and oxidase, triple sugar iron (TSI), citrate and urease testing. The API $20 \mathrm{E}$ system (bioMérieux SA, Marcy-l'Étoile, France) was used if the abovementioned tests failed to identify the gram-negative bacterium. Samples yielding 2 different bacterial species were grouped as "mixed culture," whereas samples yielding 3 or more different bacterial species were considered to be contaminated.

\section{Outcome Variables}

The cow IRCM was calculated by dividing the number of quarter cases by the days at risk (DAR) during the study and expressed as cases per 10,000 cow-days at risk. Samples taken from the same cow within 2 wk from a previous case $(\mathrm{n}=22)$ were not considered new cases and, therefore, excluded from the analysis (Barkema et al., 1998). The at-risk period for a cow started at the beginning of the survey or at the date of first calving and ended at the end of the survey or at the culling date. As dry cows can suffer from CM (Scherpenzeel et al., 2014) and CM in early lactation may originate from IMI established in the nonlactating period (Bradley and Green, 2004), dry periods were included in the at-risk period. Overall IRCM (independent of the culture results), as well as pathogen-specific IRCM (Staph. aureus, Strep. uberis, Strep. dysgalactiae, and $E$. coli, specifically) were calculated.

\section{Data Analyses}

The association between pathogen isolation and severity was tested on a data set including all CM cases (n $=845$ ). Five different logistic regression models (PROC LOGISTIC, SAS 9.4; SAS Institute Inc., Cary, NC) were fit with isolation as the outcome variable [(1) no growth vs. growth, (2) Staph. aureus isolation vs. any other culture result, (3) Strep. uberis isolation vs. any other culture result, (4) Strep. dysgalactiae isolation vs. any other culture result, and (5) E. coli isolation vs. any other culture result)] and severity (mild, moderate, 
or severe) as categorical fixed effect. Odds ratios (OR) with $95 \%$ confidence intervals were calculated.

The associations between herd hygiene and the different outcome variables [(1) overall IRCM, (2) Staph. aureus IRCM, (3) Strep. uberis IRCM, (4) Strep. dysgalactiae IRCM, and (5) E. coli IRCM] were determined using 5 mixed Poisson regression models (PROC GLIMMIX, SAS 9.4). All models contained herd as a random effect to correct for clustering of cows within herds, the natural logarithm of the number of DAR as an offset variable (Barkema et al., 1999), and herd hygiene (dirty vs. clean) as a categorical fixed effect. For each outcome, variable rate ratios (RR) with 95\% confidence intervals were calculated. Confounding by parity distribution in the herd was tested by adding the proportion of heifers in the herd (heifer DAR/total DAR) to the model as a continuous fixed effect. Parity distribution was considered to act as a confounder if the regression coefficients of herd hygiene underwent a relative change $>25 \%$. No confounding was detected. Overdispersion was evaluated for each model by calculating a dispersion parameter (Pearson $\chi^{2} / \mathrm{df}$; Dohoo et al., 2003). The power to demonstrate a significant difference between dirty and clean herds $(1-\beta$, where $\beta$ is the type II error rate) was estimated for each model using the following formula (Dohoo et al., 2003): $\mathrm{P}\left(z>Z_{\beta}\right)$, where $z=$ the standard normal variable and $Z_{\beta}=$ the calculated boundary value, and $Z_{\beta}=\sqrt{\frac{n\left(\lambda_{2}-\lambda_{1}\right)^{2}}{\lambda_{1}+\lambda_{2}}}-Z_{\alpha / 2}$, where $n=25$ (herds per group), $\lambda_{1}=$ average count of cases in clean herds, $\lambda_{2}=$ average count of cases in dirty herds and $Z_{\alpha / 2}=95$ th percentile of a standard normal distribution $=1.96$.

Because CM detection in AMS herds is different, all analyses were repeated on a subset of data excluding the 3 AMS herds. Because of the limited proportion of AMS herds, only changes in regression coefficients were calculated and reported.

\section{RESULTS}

\section{Herd Characteristics}

Thirty-two (64\%) herds participated in the DHI program, whereas 18 did not. The average herd size was 60 lactating cows (range of 16 to 240). All producers milked Holstein-Friesian cows. Cows were housed in freestalls with cubicles in 34 herds (68\%), in freestalls with deep litter bedding in 7 herds $(14 \%)$, and in tiestalls in 9 herds (18\%). Zero grazing was practiced in 10 herds $(20 \%)$. Cows were milked using an AMS in 3 herds $(6 \%)$. Forty-one producers $(82 \%)$ used individual paper towels for premilking treatment, whereas 6 producers used a cotton towel (12\%). Eight producers
(16\%) used a foaming predip. Cow teats were sprayed in 12 herds (24\%) and dipped in 29 herds (48\%) after milking. Postmilking teat disinfection was not practiced in 9 herds (18\%). In all herds, blanket dry cow therapy was applied. Dry cow therapy with long-acting antimicrobial agents was combined with an internal teat sealant for all cows in 8 herds (16\%) and for some cows in 10 (20\%) herds. Twenty-seven (54\%) producers declared never to purchase cows/young stock, whereas 23 did. During the survey, participating herds had an average BMSCC of 236,000 cells/mL (range of 85,000 to 453,000 cells $/ \mathrm{mL}$ ). On average, $47.9 \%$ of the cows per herd had an UHS of 3 or 4 (range of 15 to $77.5 \%$ ). Twenty-seven herds $(54 \%)$ were categorized as clean ( $\leq 50 \%$ of cows having UHS 3 or 4 ) and 23 as dirty ( $>50 \%$ of cows having UHS 3 or 4 ). The average proportion of heifers in a herd (heifer DAR/total DAR) was $23.8 \%$ (range of 6.0 to $45.9 \%$ ).

\section{Clinical Mastitis}

In total, $845 \mathrm{CM}$ cases from 692 cows were sampled by the producers. During the survey, $490(77.7 \%), 111$ $(17.4 \%), 30(4.7 \%), 5(0.8 \%)$, and $3(0.5 \%)$ cows suffered from 1, 2, 3, 4, and 5 cases, respectively. The population was $1,192,800$ cow-days at risk. In total, 1,032 heifers calved during the survey and 722 animals were culled.

The IRCM was estimated at 7.1 quarter cases per 10,000 cow-days at risk for the whole population and was lower in heifers (2.9 quarter cases per 10,000 cowdays at risk) compared with multiparous cows (11.0 quarter cases per 10,000 cow-days at risk). However, the IRCM in the first week after calving was higher in heifers compared with cows (Figure 1).

Forty-eight out of 50 participating producers (96\%) submitted CM samples during the study period. The number of cases per herd ranged from 0 to 107. The producers of the herds without submitted samples declared not to have observed CM cases during the study and typically milked a relatively low number of cows $(20$ and 40, respectively) in conventional milking systems. The average and median herd IRCM was 7.4 and 5.3 quarter cases per 10,000 cow-days at risk, respectively. The IRCM per herd is presented in Figure 2, showing a wide between-herd variation (range: 0-21.3 quarter cases per 10,000 cow-days at risk). Herds with an AMS had a lower average and median IRCM (4.7 and 2.6 quarter cases per 10,000 cow-days at risk, respectively; Figure 2).

\section{Pathogen Distribution and Severity}

In total, $677 \mathrm{CM}$ samples $(80.1 \%)$ were culture positive, including 87 contaminated samples (10.3\%), where- 


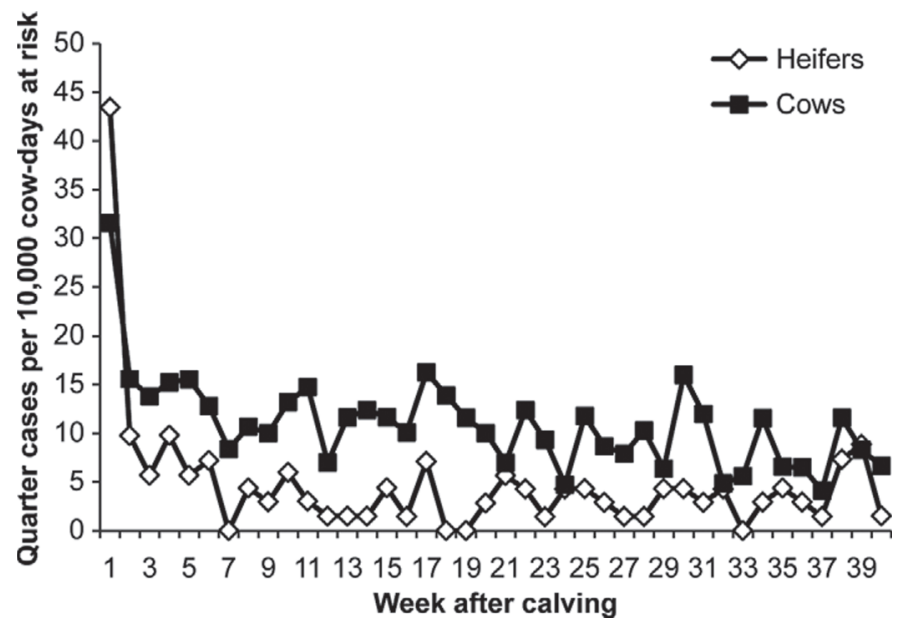

Figure 1. Incidence rate of clinical mastitis per week after calving for heifers $(\mathrm{n}=2,168)$ and multiparous cows $(\mathrm{n}=2,753)$.

as $168 \mathrm{CM}$ samples (19.9\%) yielded no growth. Streptococcus uberis was most frequently isolated (18.2\%), followed by E. coli (15.5\%), Staph. aureus $(7.3 \%)$, and Strep. dysgalactiae (7.2\%). Non-aureus staphylococci, Corynebacterium bovis, and other esculin-positive cocci besides Strep. uberis were isolated in 5.0, 3.0, and 2.1\% of the samples, respectively (Table 1). Mixed cultures were isolated in $35 \mathrm{CM}$ samples $(4.1 \%)$. Yeasts were the most frequently isolated nonbacterial pathogens (2.0\%). In $5.4 \%$ of the samples, other pathogens were isolated, including Prototheca spp. (1.4\%), Klebsiella spp. (0.8\%), Trueperella pyogenes (0.7\%), Bacillus spp. (0.6\%), Pasteurella spp. (0.5\%), Streptococcus agalactiae (0.4\%), Streptococcus canis (0.4\%), Pseudomonas aeruginosa (0.4\%), Serratia spp. (0.2\%), and molds
$(0.1 \%)$. The pathogen-specific IRCM are shown in Table 1.

The majority of the CM cases were mild (63.1\% of the cases; Table 1). Moderate severity was noticed in $29.9 \%$ of the cases and in $7.0 \%$ of the cases, producers observed severe clinical signs. In AMS herds, 30.8, 39.2 , and $40.0 \%$ of the cases were, respectively, mild, moderate, and severe. Severity was associated only with the likelihood of $E$. coli isolation $(P<0.0001$; Table 2). The likelihood of $E$. coli isolation (vs. any other culture result) was higher in severe and moderate cases compared with mild cases $[\mathrm{OR}=1.85(95 \%$ $\mathrm{CI}=1.22-2.79)$ and $\mathrm{OR}=5.04(95 \% \mathrm{CI}=2.80-9.07)$, respectively]. Escherichia coli was isolated in 11, 19, and $39 \%$ of the mild, moderate, and severe cases, respectively. Regression coefficients changed little when AMS herds were excluded from the data set $(<10 \%$ change, data not shown).

\section{Association Between Pathogen-Specific IRCM and Herd Hygiene}

Overall IRCM, Staph. aureus IRCM, Strep. uberis IRCM, Strep. dysgalactiae IRCM, and E. coli IRCM were higher in dirty herds compared with clean herds. Differences were significant for E. coli IRCM $(\mathrm{RR}=2.57 ; 95 \% \mathrm{CI}=1.36-4.85)$ and tended to be significant for overall IRCM $(\mathrm{RR}=1.49 ; 95 \% \mathrm{CI}=$ 0.95-2.33). Depending on the model, the dispersion parameter and estimated power ranged from 0.71 to 1.59 and from 0.03 to 0.99 , respectively (Table 3 ). Regression coefficients changed little when AMS herds were excluded from the data set $(<10 \%$ change; data not shown).

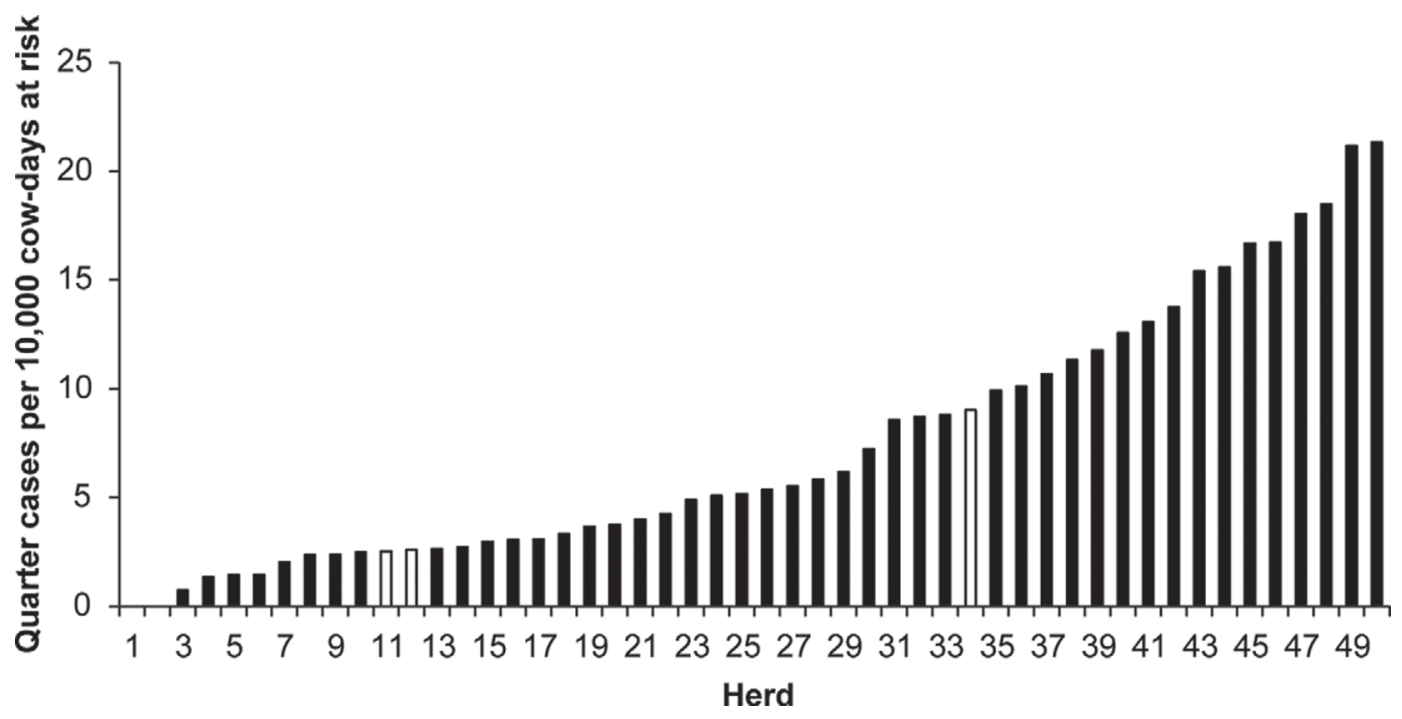

Figure 2. Incidence rate of clinical mastitis as determined through a 1-yr survey conducted on 50 randomly selected Flemish dairy herds. White bars represent automatic milking system (AMS) herds. 
Table 1. Culture results, severity, and pathogen-specific incidence rates of clinical mastitis (IRCM) from a 1-yr survey conducted on 50 randomly selected Flemish dairy herds

\begin{tabular}{|c|c|c|c|c|c|c|}
\hline \multirow[b]{2}{*}{ Culture result } & \multirow[b]{2}{*}{$\mathrm{n}$} & \multirow{2}{*}{$\begin{array}{c}\text { Cases }^{1} \\
(\%)\end{array}$} & \multicolumn{3}{|c|}{ Severity $^{2}$} & \multirow[b]{2}{*}{$\mathrm{IRCM}^{3}$} \\
\hline & & & Mild $^{2}$ & Moderate & Severe & \\
\hline Streptococcus uberis & 154 & 18.2 & 62.3 & 33.8 & 3.9 & 1.3 \\
\hline Escherichia coli & 131 & 15.5 & 45.8 & 36.6 & 17.6 & 1.1 \\
\hline Staphylococcus aureus & 62 & 7.3 & 64.5 & 30.6 & 4.8 & 0.5 \\
\hline Streptococcus dysgalactiae & 61 & 7.2 & 63.9 & 34.4 & 1.6 & 0.5 \\
\hline Non-aureus staphylococci & 42 & 5.0 & 64.3 & 26.2 & 9.5 & 0.4 \\
\hline Corynebacterium bovis & 25 & 3.0 & 72.0 & 28.0 & 0.0 & 0.2 \\
\hline Other esculin-positive cocci $^{4}$ & 18 & 2.1 & 83.3 & 16.7 & 0.0 & 0.2 \\
\hline Yeast & 17 & 2.0 & 58.8 & 23.5 & 17.6 & 0.1 \\
\hline Other pathogen & 46 & 5.4 & 60.9 & 32.6 & 6.5 & 0.4 \\
\hline Mixed culture $^{5}$ & 35 & 4.1 & 68.6 & 20.0 & 11.4 & 0.3 \\
\hline Contaminated sample $^{6}$ & 87 & 10.3 & 76.7 & 19.8 & 3.5 & 0.7 \\
\hline Total culture positive & 677 & 80.1 & 62.5 & 30.1 & 7.4 & 5.7 \\
\hline No growth & 168 & 19.9 & 65.5 & 29.2 & 5.4 & 1.4 \\
\hline Total & 845 & 100.0 & 63.1 & 29.9 & 7.0 & 7.1 \\
\hline
\end{tabular}

${ }^{1}$ Number of cases with the specific culture result/total number of cases.

${ }^{2}$ Mild $=$ only clots in milk; moderate $=$ hard quarter without general signs; severe $=$ systemic illness.

${ }^{3}$ Quarter cases per 10,000 cow-days at risk.

${ }^{4}$ Besides Streptococcus uberis.

${ }^{5}$ Isolation of 2 different pathogens.

${ }^{6}$ Isolation of 3 or more different pathogens.

\section{DISCUSSION}

To estimate the pathogen-specific IRCM in Flanders, 68 herds were randomly selected. A fair response rate of $79 \%$ was achieved. Three of the initial 53 herds were excluded from the analysis because producers admitted they did not sample all cases. Participation in the
DHI program was comparable between the study herds (64\%) and all Flemish dairy herds (60\%; K. Huijps, CRV, Alken, the Netherlands, personal communication), suggesting randomization worked well. Still, the average herd size and BMSCC were slightly higher in the study herds (60 lactating cows and 236.000 cells/ $\mathrm{mL}$, respectively) compared with all Flemish dairy

Table 2. Logistic regression models describing the association between pathogen isolation and severity of clinical mastitis

\begin{tabular}{llcccccc}
\hline Pathogen isolation $^{1}$ & Severity $^{2}$ & $\beta^{3}$ & $\mathrm{SE}$ & $\mathrm{OR}^{4}$ & $95 \% \mathrm{CI} \mathrm{OR}^{5}$ & LSM $^{6}$ & $P$-value \\
\hline No growth & Mild & Ref. & - & - & - & 0.21 & 0.60 \\
& Moderate & -0.08 & 0.19 & 0.92 & $0.63-1.34$ & 0.19 & \\
& Severe & -0.37 & 0.38 & 0.69 & $0.33-1.45$ & 0.15 & \\
Staphylococcus aureus & Mild & Ref. & - & - & - & 0.08 & 0.79 \\
& Moderate & 0.00 & 0.29 & 1.00 & $0.57-1.77$ & 0.08 & \\
Streptococcus uberis & Severe & -0.42 & 0.62 & 0.66 & $0.20-2.20$ & 0.05 & \\
& Mild & Ref. & - & - & - & 0.18 & 0.18 \\
& Moderate & 0.16 & 0.19 & 1.18 & $0.81-1.72$ & 0.21 & \\
Streptococcus dysgalactiae & Severe & -0.66 & 0.45 & 0.52 & $0.22-1.23$ & 0.10 & \\
& Mild & Ref. & - & - & - & 0.07 & 0.27 \\
& Moderate & 0.14 & 0.28 & 1.15 & $0.66-1.99$ & 0.08 & \\
Escherichia coli & Severe & -1.52 & 1.021 & 3.34 & $0.03-1.62$ & 0.02 & \\
& Mild & Ref. & - & - & - & 0.11 & $<0.0001$ \\
& Moderate & 0.61 & 0.21 & 1.85 & $1.22-2.79$ & 0.19 & \\
& Severe & 1.62 & 0.30 & 5.04 & $2.80-9.07$ & 0.39 & \\
\hline
\end{tabular}

${ }^{1}$ Outcome variable with $1=$ isolation of the pathogen and $0=$ any other culture result.

${ }^{2}$ Mild $=$ only clots in milk; moderate $=$ hard quarter without general signs; severe $=$ systemic illness .

${ }^{3}$ Regression coefficient

${ }^{4} \mathrm{OR}=$ odds ratio.

${ }^{5} 95 \%$ CI around OR.

${ }^{6}$ Proportion of cases with the specific culture result compared with the total number of cases with the specific severity.

${ }^{7}$ Overall $P$-value.

${ }^{8}$ Ref. $=$ reference 
Table 3. Poisson mixed regression models describing the association between pathogen-specific incidence rates of clinical mastitis (IRCM) and herd hygiene

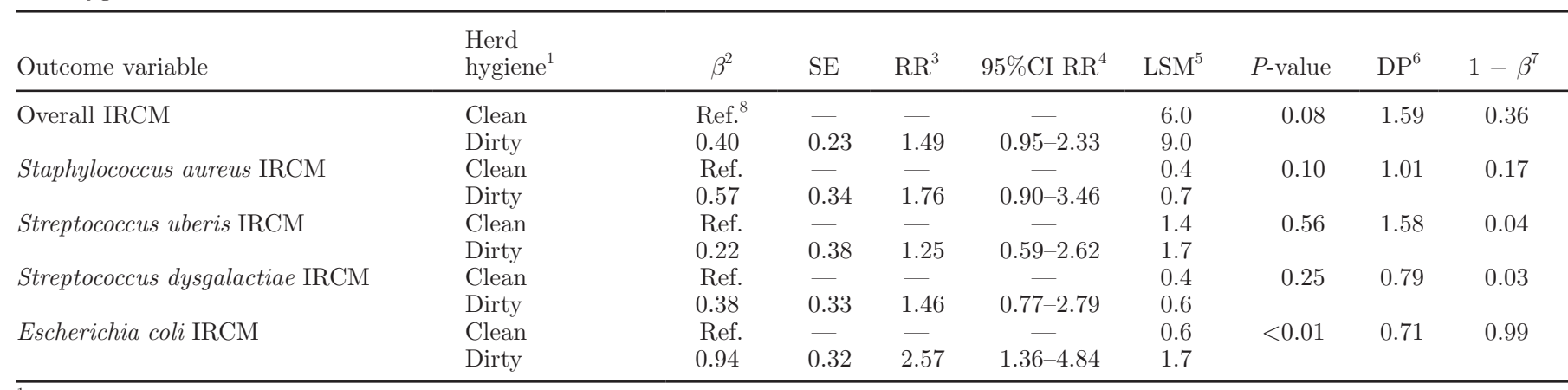

${ }^{1}$ Determined by recording the udder hygiene score (UHS; scale 1 to 4; Schreiner and Ruegg, 2003) of cows during 2 herd visits. Herds with more than half of the cows having UHS 3 or 4 were categorized as dirty $(\mathrm{n}=23)$; other herds were categorized as clean $(\mathrm{n}=27)$.

${ }^{2} \beta=$ regression coefficient.

${ }^{3}$ Rate ratio.

${ }^{4} 95 \%$ CI of RR.

${ }^{5}$ Quarter cases per 10,000 cow-days at risk.

${ }^{6}$ Dispersion parameter, calculated by dividing the Pearson $\chi^{2}$ by its degrees of freedom (Dohoo et al., 2003).

${ }^{7}$ Estimated power to demonstrate a significant difference between dirty and clean herds.

${ }^{8}$ Ref. $=$ reference.

herds [50 lactating cows (Federal Public Service Economy, Small and Medium Enterprises, Self-Employed, and Energy, 2011) and 214.000 cells/mL (Milk Control Centre Flanders, 2013), respectively], suggesting some selection bias. As high BMSCC was found to be associated with higher Staph. aureus and Strep. dysgalactiae IRCM and lower E. coli IRCM (Barkema et al., 1999; Olde Riekerink et al., 2008), we might have underestimated E. coli IRCM and overestimated Staph. aureus and Strep. dysgalactiae IRCM.

Similar to other research (Barkema et al., 1998; McDougall et al., 2007), heifers had a lower IRCM in general but a higher IRCM in early lactation compared with multiparous cows. The latter findings stress the importance of prevention and control of heifer mastitis (De Vliegher et al., 2012) and the need to understand differences between pathogens associated with this disease. The mean herd IRCM (expressed as quarter cases per 10,000 cow-days at risk) was estimated considerably lower (7.4) than what could have been expected from a recent internet questionnaire indicating that $46 \%$ of the Flemish dairy cows suffer at least once per year from CM (P. Passchyn, S. Piepers, and S. De Vliegher, Ghent University, Ghent, Belgium, unpublished data). Based on the internet questionnaire, one would expect at least 1,380 cases $(46 \% \times 60$ lactating cows $\times 50$ herds), whereas we collected 845 samples. Because methodology and especially selection criteria differ between studies, caution is required in comparing results between CM surveys (Olde Riekerink et al., 2008), especially as the producers participating in the aforementioned online questionnaire estimated the
IRCM lacking accurate data, as the majority admitted they were not keeping disease records. Yet, our figure differed little from figures estimated by Barkema et al. (1998) in the Netherlands (7.6, 7.0, and 6.9 for herds with low, medium, and high BMSCC, respectively) and Wolff et al. (2012) in Sweden (7.2). The IRCM was estimated lower in France and Canada (5.5 and 6.4, respectively), but higher in England and Wales (12.9), Norway (8.6), Finland (10.6) and Denmark (12.8; Barnouin et al., 2005; Bradley et al., 2007; Olde Riekerink et al., 2008; Wolff et al., 2012). Herds were randomly selected in some studies (Barkema et al., 1998; Bradley et al., 2007; Wolff et al., 2012) and conveniently selected in others (Barnouin et al., 2005; Olde Riekerink et al., 2008). In contrast to the studies in which the animals were randomly selected as well, no inclusion criteria were applied in our study, underlining the external validity of our data.

The pathogen distribution in this survey corresponded with those of Flemish CM samples submitted to the laboratories of both MCC Flanders ( $\mathrm{n}=4,468$; Milk Control Centre Flanders, 2012) and the M-team (Ghent University, Merelbeke, Belgium; $\mathrm{n}=329$ ). In the 3 data sets, E. coli and esculin-positive cocci, including Strep. uberis, were the most frequently isolated pathogens. Similar to other regions in the world (Bradley et al., 2007; Oliveira et al., 2013), environmental pathogens appear to be the most common cause of CM in Flanders. Staphylococcus aureus was less frequently isolated in our study ( $7.3 \%$ of the samples) compared with CM studies conducted in Canada (10.3\% of the samples; Olde Riekerink et al., 2008) and Ireland (23\% of the 
samples; Keane et al., 2013), suggesting that a different focus in clinical mastitis prevention is required for each country. Both in this and in other studies (Bradley et al., 2007; Olde Riekerink et al., 2008; Keane et al., 2013; Oliveira et al., 2013), a relative large proportion of cases were culture negative. Spontaneous cure, low bacterial viability, and pathogens not growing in standard culture media (Mycoplasma spp.) might explain this high proportion (Taponen et al., 2009). Freezing and thawing of the samples might have decreased the culture sensitivity of E. coli (Schukken et al., 1989) but was required to allow convenient transportation of samples by the herd veterinarians. As the sensitivity of detecting IMI using a single milk sample was found to be higher for Staph. aureus compared with other pathogens (Dohoo et al., 2011), we might have overestimated the Staph. aureus IRCM compared with the IRCM by other pathogens.

Clinical signs were mostly mild. However, we should mention that the clinical signs were recorded by the producers who might have missed subtle signs of systemic illness (e.g., fever) in some cases. Compared with a CM study in large herds in Wisconsin (Oliveira et al., 2013), the proportion of moderate and severe cases was smaller (29.9 and $7 \%$ vs. 36.9 and $15.3 \%$, respectively). Still, in the latter study, E. coli was more frequently isolated compared with our study (21.6 vs. $15.3 \%$ of the cases). Additionally, as producers were rewarded per collected milk sample to keep them motivated, it is not unlikely that very mild cases in our study were sampled. Nevertheless, cases might also have been missed. Especially in dry cows and AMS herds, where detection intensity could potentially have been less, resulting in some bias and an underestimation of the true IRCM. Isolation of $E$. coli was more likely in moderate and severe cases compared with mild cases. Still, E. coli could only be isolated in less than half of the severe cases. Using $E$. coli mastitis as synonym for severe mastitis should for that reason be discouraged. Instead, dairy producers and herd veterinarians should be informed that other pathogens besides $E$. coli can cause severe CM and that E. coli can also cause mild CM cases. Bacteriological culture of mild, moderate, and severe cases is required to estimate the herd pathogen distribution and a basis for an effective herd-specific mastitis treatment and control plan.

The accuracy of measuring herd hygiene by scoring the udder hygiene of a limited number of cows during 2 herd visits can be debated. Nevertheless, we observed a higher overall and E. coli IRCM in dirty herds compared with clean herds, which corresponds well with British research demonstrating a higher risk of $\mathrm{CM}$ in general and E. coli $\mathrm{CM}$ specifically in cows with dirty udders
(Breen et al., 2009). However, and in contrast to the British study, we cannot claim that dirty cows were more likely to have CM because hygiene was measured at the herd level, potentially causing ecological bias (Dohoo et al., 2003). Yet, evaluating and improving udder and herd hygiene could reduce IRCM in Flanders. Interestingly, results in both studies demonstrated a much stronger association with E. coli CM compared with Strep. uberis CM. Although the power to detect a difference in Strep. uberis IRCM between dirty and clean herds in our study was very low and although Strep. uberis is considered as an environmental pathogen, cow-to-cow transmission might occur (Zadoks et al., 2003). We speculate that in several of the herds included in our study, cow-adapted Strep. uberis strains were causing CM. At the least, our findings indicate that improving hygiene will reduce the number of $E$. coli cases but will not have a large effect on Strep. uberis IRCM.

\section{CONCLUSIONS}

The mean and median IRCM in Flemish dairy herds was estimated at 7.4 and 5.3 quarter cases/10,000 cowdays at risk and showed high between-herd variation as indicated by the wide range $(0-21.3)$. The IRCM of heifers compared with multiparous cows was lower throughout the entire lactation, yet higher in early lactation. Streptococcus uberis and E. coli were the most frequently isolated pathogens. Clinical signs were mild in most cases. Isolation of E. coli was more likely in moderate and severe cases compared with mild cases. Yet, less than half of the severe cases had E. coli as culture result. Overall and E. coli IRCM were higher in dirty compared with clean herds.

\section{ACKNOWLEDGMENTS}

This research was financed by a $\mathrm{PhD}$ grant (no. 101206) from the Agency for Innovation by Science and Technology in Flanders (IWT Vlaanderen, Brussels, Belgium), the Flemish cattle monitoring project ("Veepeiler Rund"), headed by the Flemish Animal Health Service (DGZ-Vlaanderen, Lier, Belgium), as well as the Flemish Government (Departement Landbouw en Visserij, Afdeling Duurzame Landbouwontwikkeling, Brussels, Belgium). The authors thank the Cattle Breeding Association (CRV, Alken, the Netherlands) for access to DHI records, Koen Lommelen (MCC Flanders, Lier, Belgium) for collecting BMSCC data, and Jo Maris and Hans Van Loo (DGZ-Vlaanderen) for access to cow records of the identification and registration system. Last but not least, we thank all participating producers and herd veterinarians. 


\section{REFERENCES}

Bannerman, D. D., M. J. Paape, J.-W. Lee, X. Zhao, J. C. Hope, and P. Rainard. 2004. Escherichia coli and Staphylococcus aureus elicit differential innate immune responses following intramammary infection. Clin. Diagn. Lab. Immunol. 11:463-472. http://dx.doi. org/10.1128/CDLI.11.3.463-472.2004.

Barkema, H. W., Y. H. Schukken, T. J. Lam, M. L. Beiboer, G. Benedictus, and A. Brand. 1999. Management practices associated with the incidence rate of clinical mastitis. J. Dairy Sci. 82:1643-1654. http://dx.doi.org/10.3168/jds.S0022-0302(99)75393-2.

Barkema, H. W., Y. H. Schukken, T. J. Lam, M. L. Beiboer, H. Wilmink, G. Benedictus, and A. Brand. 1998. Incidence of clinical mastitis in dairy herds grouped in three categories by bulk milk somatic cell counts. J. Dairy Sci. 81:411-419. http://dx.doi. org/10.3168/jds.S0022-0302(98)75591-2.

Barnouin, J., S. Bord, S. Bazin, and M. Chassagne. 2005. Dairy management practices associated with incidence rate of clinical mastitis in low somatic cell score herds in France. J. Dairy Sci. 88:37003709. http://dx.doi.org/10.3168/jds.S0022-0302(05)73056-3.

Bradley, A. J. 2002. Bovine mastitis: An evolving disease. Vet. J. 164:116-128. http://dx.doi.org/10.1053/tvjl.2002.0724.

Bradley, A. J., and M. J. Green. 2004. The importance of the nonlactating period in the epidemiology of intramammary infection and strategies for prevention. Vet. Clin. North Am. Food Anim. Pract. 20:547-568. http://dx.doi.org/10.1016/j.cvfa.2004.06.010.

Bradley, A. J., K. A. Leach, J. E. Breen, L. E. Green, and M. J. Green. 2007. Survey of the incidence and aetiology of mastitis on dairy farms in England and Wales. Vet. Rec. 160:253-258.

Breen, J. E., M. J. Green, and A. J. Bradley. 2009. Quarter and cow risk factors associated with the occurrence of clinical mastitis in dairy cows in the United Kingdom. J. Dairy Sci. 92:2551-2561. http://dx.doi.org/10.3168/jds.2008-1369.

Burvenich, C., V. Van Merris, J. Mehrzad, A. Diez-Fraile, and L. Duchateau. 2003. Severity of $E$. coli mastitis is mainly determined by cow factors. Vet. Res. 34:521-564. http://dx.doi.org/10.1051/ vetres:2003023.

De Vliegher, S., L. K. Fox, S. Piepers, S. McDougall, and H. W. Barkema. 2012. Invited review: Mastitis in dairy heifers: Nature of the disease, potential impact, prevention, and control. J. Dairy Sci. 95:1025-1040. http://dx.doi.org/10.3168/jds.2010-4074.

Dohoo, I., M. Wayne, and H. Stryhn. 2003. Sample-size determination (Pages 39-49), Modelling Count and Rate Data (Pages 445-466), and Ecological and Group-level Studies (Pages 773-788) in Veterinary Epidemiologic Research. 1st ed. I. Dohoo, W. Martin, and H. Stryhn, ed. AVC Inc., Charlottetown, Canada.

Dohoo, I. R., J. Smith, S. Andersen, D. F. Kelton, and S. Godden. 2011. Diagnosing intramammary infections: Evaluation of definitions based on a single milk sample. J. Dairy Sci. 94:250-261. http://dx.doi.org/10.3168/jds.2010-3559.

Federal Public Service Economy, Small and Medium Enterprises, Self-Employed, and Energy. 2011. Landbouwtelling 2010. Accessed July 20, 2012. http://statbel.fgov.be/ $\mathrm{nl} /$ binaries/3.1.3.6.1.Landbouw\%20definitief\%20T\%202010\%2005 _tcm325-118744.xls.

Keane, O. M., K. E. Budd, J. Flynn, and F. McCoy. 2013. Pathogen profile of clinical mastitis in Irish milk-recording herds reveals a complex aetiology. Vet. Rec. 173:17 http://dx.doi.org/10.1136/ vr.101308.

Ma, Y., C. Ryan, D. M. Barbano, D. M. Galton, M. A. Rudan, and K. J. Boor. 2000. Effects of somatic cell count on quality and shelf-life of pasteurized fluid milk. J. Dairy Sci. 83:264-274. http://dx.doi. org/10.3168/jds.S0022-0302(00)74873-9.

McDougall, S., K. E. Agnew, R. Cursons, X. X. Hou, and C. R. Compton. 2007. Parenteral treatment of clinical mastitis with tylosin base or penethamate hydriodide in dairy cattle. J. Dairy Sci.
90:779-789. http://dx.doi.org/10.3168/jds.S0022-0302(07)71562$\mathrm{X}$.

Milk Control Centre Flanders. 2012. Annual Report. Milk Control Centre Flanders, Lier, Belgium.

Milk Control Centre Flanders. 2013. Annual Report. Milk Control Centre Flanders, Lier, Belgium.

NMC (National Mastitis Council). 1999. Laboratory Handbook on Bovine Mastitis. Rev. ed. National Mastitis Council Inc., Madison, WI

Olde Riekerink, R. G. M., H. W. Barkema, D. F. Kelton, and D. T. Scholl. 2008. Incidence rate of clinical mastitis on Canadian dairy farms. J. Dairy Sci. 91:1366-1377. http://dx.doi.org/10.3168/ jds.2007-0757.

Oliveira, L., C. Hulland, and P. L. Ruegg. 2013. Characterization of clinical mastitis occurring in cows on 50 large dairy herds in Wisconsin. J. Dairy Sci. 96:7538-7549. http://dx.doi.org/10.3168/ jds.2012-6078

Piepers, S., L. De Meulemeester, A. de Kruif, G. Opsomer, H. W. Barkema, and S. De Vliegher. 2007. Prevalence and distribution of mastitis pathogens in subclinically infected dairy cows in Flanders, Belgium. J. Dairy Res. 74:478-483.

Pinzón-Sánchez, C., and P. L. Ruegg. 2011. Risk factors associated with short-term post-treatment outcomes of clinical mastitis. J. Dairy Sci. 94:3397-3410. http://dx.doi.org/10.3168/jds.20103925

Santos, M. V., Y. Ma, and D. M. Barbano. 2003. Effect of somatic cell count on proteolysis and lipolysis in pasteurized fluid milk during shelf-life storage. J. Dairy Sci. 86:2491-2503. http://dx.doi. org/10.3168/jds.S0022-0302(03)73843-0.

Scherpenzeel, C. G. M., I. E. M. den Uijl, G. van Schaik, R. G. M. Olde Riekerink, and T. J. G. M. Lam. 2014. Evaluation of the use of dry cow antibiotics in low somatic count cows. J. Dairy Sci. 97:3606-3614. http://dx.doi.org/10.3168/jds.2013-7655.

Schreiner, D. A., and P. L. Ruegg. 2003. Relationship between udder and leg hygiene scores and subclinical mastitis. J. Dairy Sci. $\quad 86: 3460-3465 . \quad$ http://dx.doi.org/10.3168/jds.S00220302(03)73950-2.

Schukken, Y. H., J. Gunther, J. Fitzpatrick, M. C. Fontaine, L. Goetze, O. Holst, J. Leigh, W. Petzl, H. J. Schuberth, A. Sipka, D G. E. Smith, R. Quesnell, J. Watts, R. Yancey, H. Zerbe, A Gurjar, R. N. Zadoks, and H. M. Seyfert. 2011. Host-response patterns of intramammary infections in dairy cows. Vet. Immunol. Immunopathol. 144:270-289. http://dx.doi.org/10.1016/j. vetimm.2011.08.022

Schukken, Y. H., J. A. H. Smit, F. J. Grommers, D. Vandegeer, and A. Brand. 1989. Effect of freezing on bacteriologic culturing of mastitis milk samples. J. Dairy Sci. 72:1900-1906. http://dx.doi. org/10.3168/jds.S0022-0302(89)79309-7.

Smith, K. L., and J. S. Hogan. 1993. Environmental mastitis. Vet. Clin. North Am. Food Anim. Pract. 9:489-498.

Taponen, S., L. Salmikivi, H. Simojoki, M. T. Koskinen, and S. Pyörälä. 2009. Real-time polymerase chain reaction-based identification of bacteria in milk samples from bovine clinical mastitis with no growth in conventional culturing. J. Dairy Sci. 92:26102617. http://dx.doi.org/10.3168/jds.2008-1729.

Wolff, C., M. Espetvedt, A. K. Lind, S. Rintakoski, A. Egenvall, A. Lindberg, and U. Emanuelson. 2012. Completeness of the disease recording systems for dairy cows in Denmark, Finland, Norway and Sweden with special reference to clinical mastitis. BMC Vet. Res. 8:131 http://dx.doi.org/10.1186/1746-6148-8-131.

Zadoks, R. N., B. E. Gillespie, H. W. Barkema, O. C. Sampimon, S. P. Oliver, and Y. H. Schukken. 2003. Clinical, epidemiological and molecular characteristics of Streptococcus uberis infections in dairy herds. Epidemiol. Infect. 130:335-349. http://dx.doi. org/10.1017/S0950268802008221. 